\title{
Aquatic Insect Functional Feeding Groups in a Mountain Stream with a Series of Check Dams in Northern Thailand
}

(Serangga Akuatik Kumpulan Suapan Berfungsi di Aliran Air Gunung dengan Siri Halangan Empangan di Utara Thailand)

\author{
Phuchiwan Suriyawong*, Decha Thapanya, Elizabeth A. Bergey \& Porntip ChantaramongKol
}

\begin{abstract}
A series of check dams (or small dams in shallow streams) have been placed on many streams throughout Thailand and the number of them continue to increase. Check dam construction activities have been emphasized by the government and private sector entities over the last decade to prevent severe flood or drought due to changes in rainfall patterns. This study evaluated distribution of functional feeding groups (FFG) in a stream with a high density of check dams. Twelve sampling sites at three altitudes (500, 900 and $1500 \mathrm{~m}$ asl) included undammed and nearby dammed sections (above and below check dams) were used. Aquatic insects were collected monthly at each site for a year and categorized into FFG. Aquatic insect composition of undammed and above dam sites was different. Abundance within each FFG at above dam sites significantly differed from undammed sites. Taxonomic richness at 1500 and $900 \mathrm{~m}$ altitudes was decreased at above dam sites compared with the corresponding undammed sites, whereas above dam sites of $500 \mathrm{~m}$ altitude had higher richness than undammed site. High abundance of predators and collector-gatherers associated with reservoirs and fine sediment accumulation above dams, where filter-feeders were scarce. Shredder abundance varied among sites and was highest where leaf packs were most abundant. Scrapers were least abundant group and inconsistent with the dams. Distribution of FFG was similar to changes in other regulated streams. The composition of FFG reflected the stream ecosystem conditions through adaptation of communities to stream habitat and food resources, including those associated with check dam construction.
\end{abstract}

Keywords: Habitat alteration; regulated streams; shredders; small dams; stream alteration

\section{ABTRAK}

Satu siri halangan empangan penyekat (atau empangan kecil di sungai cetek) telah digunakan di kebanyakan sungai di seluruh Thailand dan bilangannya terus meningkat. Pembinaan halangan empangan telah ditekankan oleh kerajaan dan sektor swasta sejak sedekad yang lalu untuk mencegah banjir yang teruk atau kemarau akibat perubahan pola hujan. berkepadatan tinggi.Dua belas lokasi persampelan di tiga ketinggian (500, 900 dan 1500 m) termasuk bahagian bawah dan yang berhampiran (empangan atas dan bawah) telah digunakan. Serangga akuatik dikumpulkan setiap bulan di setiap tapak selama setahun dan dikategorikan ke dalam FFG. Komposisi serangga akuatik dari tapak empangan dan tak terempang adalah berbeza. Kelimpahan dalam setiap FFG di atas tapak empangan amat berbeza daripada tak terempang yang tidak dapat dijelaskan. Kekayaan taksonomi pada ketinggian 1500 dan 900 m menurun apabila melebihi ketinggian tapak empangan berbanding dengan yang tak terempang, sedangkan tapak empangan yang melebihi ketinggian $500 \mathrm{~m}$ mempunyai kekayaan taksonomi yang lebih tinggi daripada kawasan tak terempang. Kebanyakan kelimpahan pemangsa dan pemungut dikaitkan dengan takungan dan pengumpulan sedimen yang halus di atas empangan dengan penapis pemakan jarang ditemui. Kelimpahan pencincang berbeza antara lokasi dengan lokasi daun paling rimbun mencatatkan pengumpulan tertinggi. Pengikis adalah kumpulan yang paling sedikit dan tidak tekal dengan empangan. Pengagihan FFG adalah sama dengan perubahan dalam aliran lain yang dikawal. Komposisi FFG mencerminkan keadaan ekosistem sungai melalui adaptasi masyarakat untuk pengaliran habitat dan sumber makanan, termasuk yang berkaitan dengan pembinaan halangan empangan.

Kata kunci: Empangan kecil; pencincang; pengubahan sungai; perubahan aliran; perubahan habitat

\section{INTRODUCTION}

Check dams refer to small dams built across the direction of water flow in shallow water channels or streams. Traditionally, Thai people use check dams for diverting water from low-land rivers to agricultural areas. In mountainous areas, check dams in Thailand were originally used to maintain soil moisture during forest restoration and to prevent sediment deposition in downstream reservoirs. The original check dam model produced a series of small local-style check dams in degraded forest areas. Later, construction of check dams in national parks was promoted for sediment storage, velocity reduction and water storage; 
these dams included temporary, semi-permanent and permanent check dams. As a result, there has been a rapid increase in the number of check dams, as check dam construction has become a popular activity of local administrators and private sector entities and construction activities continue, with the goals of forest restoration, velocity reduction and water storage. A high density of check dams may have little benefit on water storage and forest restoration due to excess of soil moisture. Dam construction that ignores stream characteristics may introduce unsuitable size and construction materials of dams at the locations. For example, over-height dam wall may cut down flow to downstream; high-strength concrete dams may store water at low-land large streams and temporary permeable dams may be suitable for headwaters to protect diversity of aquatic communities. Flow obstruction by dams changes flow patterns and habitat characteristics that consequently influence stream organisms (Bunn \& Arthington 2002). Post-dam changes in the streambed may help mitigate the disturbance and may enable recolonization of insects adapted to the changed conditions (Wallace 1990).

Aquatic insects are common organisms in streams and are commonly used as indicators of water quality (Dudgeon 1999). They consume diverse food resources and feeding strategies are used to categorize them into functional feeding groups (FFG), including shredders, collectors (both filter-feeders and gatherers), scrapers and predators. Shredders play a major role in mountain streams because they convert plant material into nutrients and food for other stream organisms (Graça 2001). Specifically, shredders convert riparian-derived leaf litter (a form of imported organic matter into water bodies and the main energy source for forested mountain streams) into insect biomass and into smaller, more easily processed organic particles (Benfield 2006). Additionally, the consumption of leaf litter results in the excretion of ammonia - a nitrogen form that is readily used by other organisms (Covich et al.2004). The breakdown of leaves into fine particles enhances microbial decomposition (Prather et al. 2013). Microbes that colonize leaves and increase palatability of leaves for shredders decompose the now-smaller leaf detritus into dissolved organic matter and nutrients (Allan \& Castillo 2007). Fine particles are gathered and consumed by collectors. Collector-filter feeders use modified body parts or construct nets to filter particles in water column. Collector-gatherers feed on deposited organic sediment. Microbial biomass on small detrital particles enhances food quality and growth rates of gatherers (Cummins \& Klug 1979). Scrapers use their adapted mouthparts to graze on periphyton, such as attached algae (Merritt \& Cummins 2006). In flowing water, many scrapers have adapted to maintain their position on exposed substrates, where algae are most abundant. The adaptations include dorso-ventral flattening of the body or using ventral suckers. Predators consume living animal tissue as the dominant food type and have specific adaptations to capture prey.
Huay Kaew Stream is located in Doi Suthep-Pui National Park and drains into Chiang Mai University's reservoir, which is the main water supply for the university. Doi Suthep-Pui plays a major role in the economy of Chiang Mai City and retains a highly diverse flora and fauna. Since 2005, a series of check dams were built along Huay Kaew Stream (more than forty dams in six kilometers of stream), but possible effects of altered habitats on stream function and functional feeding groups have not yet been studied. This study investigated how functional feeding groups were distributed along the stream by sampling three stream sections at different altitudes that had different discharge (Suriyawong et al. 2015b). Specifically, the study combined sites upstream and downstream from representative dams where aquatic insect compositions were modified (Suriyawong et al. 2015a). We tested the hypothesis that the distribution of functional feeding groups in above-sites differed from the corresponding below-dam sites and undammed sites, which would indicate possible system-wide effects of check dams on functional feeding group composition.

\section{MATERIALS AND METHODS}

Doi Suthep-Pui National Park is situated in Chiang Mai Province in northern Thailand. The altitude of Doi SuthepPui ranges from 330 to $1685 \mathrm{~m}$ asl. and the average annual rainfall ranges from 1670 to $2094 \mathrm{~mm}$ (Blakesley et al. 2002). The forest is mainly evergreen forest (above 950 $\mathrm{m}$ asl) and deciduous forest (below $950 \mathrm{~m}$ asl) and is a combination of deciduous dipterocarp-oak forest in dry areas and mixed evergreen-deciduous forest in riparian areas (Elliott 1994; Putiyanan \& Maxwell 2006). Huay Kaew Stream is a perennial stream that flows from near the top of the mountain to the east, where it eventually flows into an irrigation canal.

Study sites were located along Huay Kaew Stream and represented check dams at three different altitudes (500, 900 and $1500 \mathrm{~m}$ asl) (Figure 1). Each of the three altitudes included an undammed site and two to four impacted sites (above and below check dams), as listed in Table 1. The undammed sites were located upstream of check dams, well beyond the effect of these dams. The impact sites were located in the five-meter areas upstream (above) and downstream (below) each check dam. The sampling sites at the altitude of $1500 \mathrm{~m}$ (A1-A4) were located in the headwaters and the two check dams were made of ferroconcrete. Site A4 was above a particularly large checking dam (with a height of $3 \mathrm{~m}$ and length of 20 $\mathrm{m})$, forming a sizable reservoir and the stream immediately below the dam was usually dry. At $900 \mathrm{~m}$ altitude, the three sampling sites (B1 - B3) were located around the Sai Yoi waterfall area, which had a rock-fill check dam. At $500 \mathrm{~m}$ altitude, an undammed site (C1) and four impact sites were located above and below two concrete check dams (C2 $\mathrm{C} 3$ and $\mathrm{C} 4-\mathrm{C} 5$ ) in the vicinity of a bedrock waterfall.

Canopy cover was recorded in triplicate, using a densitometer at the center of the stream. Aquatic insects 


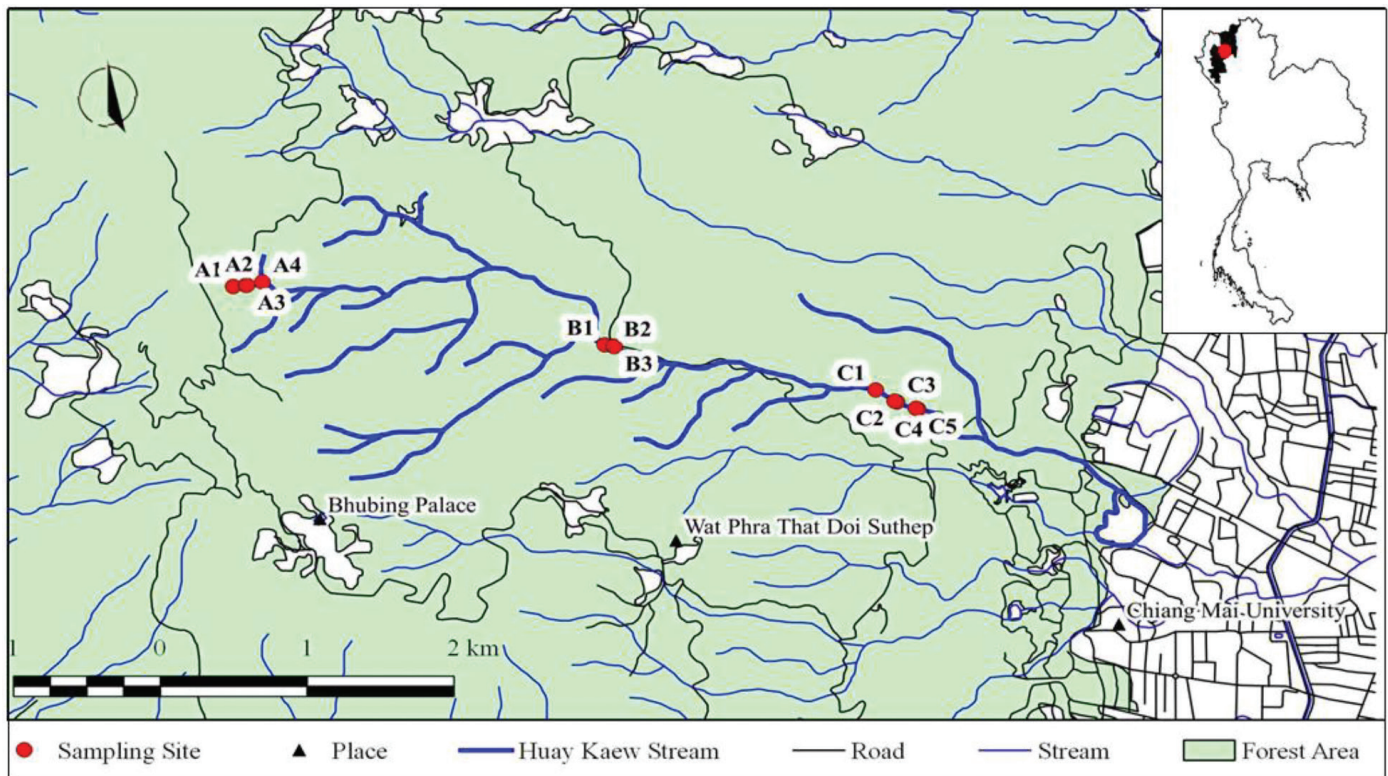

FIGURE 1. Twelve sampling sites at Huay Kaew Stream, DoiSuthep-Pui National Park, Chiang Mai, Thailand

TABLE 1. Physical characteristics and aquatic insect composition metrics at twelve sampling sites along Huay Kaew stream

\begin{tabular}{lccccc}
\hline & Sites & $\begin{array}{c}\text { Location } \\
\left(18^{\circ} \mathrm{N}, 98^{\circ} \mathrm{E}\right)\end{array}$ & $\begin{array}{c}\text { Altitude } \\
(\text { asl. })\end{array}$ & $\begin{array}{c}\text { Canopy } \\
\text { cover }(\%)\end{array}$ & $\begin{array}{c}\text { Average leaf pack ratio } \\
(\%)\end{array}$ \\
\hline A1 & undammed & $49.346,53.545$ & 1522 & 89 & 27 \\
A2 & above dam & $49.351,53.594$ & 1453 & 93 & 8 \\
A3 & below dam & $49.352,53.598$ & 1453 & 93 & 33 \\
A4 & above dam & $49.364,53.659$ & 1419 & 45 & 8 \\
\hline B1 & undammed & $49.115,54.985$ & 876 & 85 & 3 \\
B2 & above dam & $49.071,55.186$ & 873 & 84 & 63 \\
B3 & below dam & $49.107,55.024$ & 873 & 88 & 27 \\
C1 & undammed & $48.934,56.036$ & 562 & 78 & 8 \\
C2 & above dam & $48.890,56.110$ & 512 & 77 & 9 \\
C3 & below dam & $48.886,56.119$ & 512 & 88 & 5 \\
C4 & above dam & $48.868,56.171$ & 504 & 93 & 10 \\
C5 & below dam & $48.858,56.201$ & 504 & 90 & \\
\hline
\end{tabular}

were collected monthly from March 2011 to February 2012 at all sampling sites, using a D-frame pond net (mesh size $0.5 \mathrm{~mm}$ ) within a streambed area of 0.08 $\mathrm{m}^{2} / \mathrm{sample}$. At each site, ten samples were taken in proportion to the types of available habitats (i.e. clay, sand, gravel, cobble, boulder, leaf pack and streamside vegetation). The collected samples were preserved in $70 \%$ ethanol for later sorting and insect identification in the laboratory. Identifications were based mainly on Dudgeon (1999), Morse et al. (1994) and Yule and Yong (2004). Aquatic insect taxa were allocated to functional feeding groups, following designations in Cummins et al. (2005), Dudgeon (1999), Merritt and Cummins (2006) and Ramírez and Gutiérrez-Fonseca (2014). Because these sources are not Thailand-specific, gut contents of insects were inspected and combined with observations on feeding modes and mouthpart morphology (the feeding apparatus) to verify functional feeding group assignment. Insect guts that mostly contained diatoms and algae were classified as scrapers. Shredders had guts containing mainly leaf and wood fragments. Collectors had a dominance of fine detritus in their guts and guts of predators mainly contained parts of animals.

A hierarchical cluster dendrogram based on BrayCurtis dissimilarity was produced to compare insect composition among sites. Two-way ANOVA was used to analyze difference in insect abundance and taxon richness among FFG and sites. Difference of shredder abundance among altitudes was analyzed by one-way ANOVA. Pearson correlation was used to analyze the relationship between the ratio of shredders and proportion of leaf pack habitat and between the ratio of scrapers and canopy cover. All tests were analyzed using $\mathrm{R}$ version 3.4.2 ( $\mathrm{R}$ Core Team 2013). 


\section{RESULTS}

Collected aquatic insects comprised of 40,178 individuals and 386 identified taxa. Aquatic insect assemblages at undammed sites differed from at above dam sites, whereas below dam sites were similar to undammed sites at sites A and $\mathrm{B}$, but not at site $\mathrm{C}$ (Figure 2).

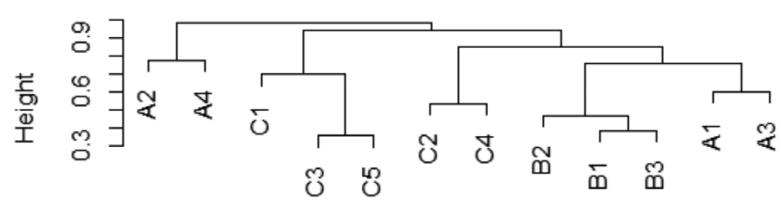

FIGURE 2. Dendrogram shows the hierarchical cluster analysis of aquatic insect abundance at each sampling site. Undammed sites (A1, B1 and $\mathrm{C} 1$ ) are separated from the corresponding above dam sites (A2, A4, B2, C2 and C4)

FFG abundance had significant difference between undammed and above-dam sites $(d f=2, p<0.05)$. Total insect abundance at undammed sites was higher than the corresponding dam sites. The most abundant group was collectors $(37.8 \%$ were collector-gatherers and $26.6 \%$ were filter-feeders). Overall proportions of predators, shredders and scrapers were $14.9 \%, 13 \%$ and $7.7 \%$, respectively. The number of gatherers in the study stream was significantly higher than scrapers $(d f=4$, $p<0.05)$. The highest density of shredders, filterers and scrapers was found at undammed sites (B1, C1 and A1, respectively), whereas the highest number of gatherers and predators was at A4 (an above dam site). Relative abundance of FFG at each sampling site varied (Figure 3). The proportion of filter-feeders was very low above dam sites (A2, A4, B2, C2 and C4) compared with other sites, whereas the proportion of collector-gatherers was higher at these above dam sites at the same altitude, except at site B2. Above dam sites had higher proportion of predators than the corresponding undammed and below dam sites. Relative abundance of shredders at $900 \mathrm{~m}$ altitude (B sites) was distinctly higher than at other altitudes $(d f=$ $2, p<0.01$ ). Scrapers were scarce at sites A4 (above dam site) and $\mathrm{C} 1$ (undammed site).

The number of taxa of predators, collector-gatherers, shredders, scrapers and filter-feeders was 155, 148, 34, 32 and 21 , respectively. Together, these numbers exceed the total number of taxa because some taxa are in different FFG (e.g. beetles may be predators as larvae and collectorgatherers as adults). The taxonomic richness of predators and gatherers were significantly higher than other FFG $(d f=4,53, p<0.05)$. Although the taxonomic richness within each FFG at undammed sites did not significantly differ from the corresponding above dam sites $(d f=2,53$, $p>0.05$ ), total taxonomic richness at above dam sites was decreased at high altitude ( $1500 \mathrm{~m}$ and $900 \mathrm{~m}$ altitudes) and increased at low altitude (500 m altitude) compared with the corresponding undammed sites.

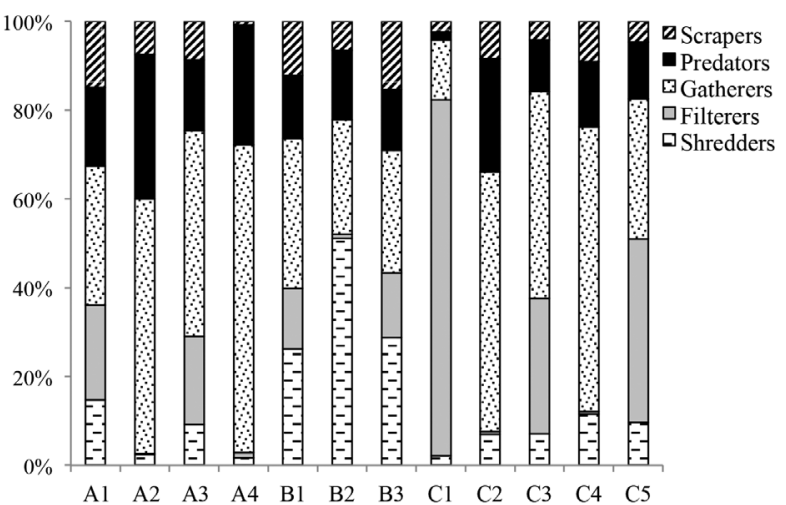

FIGURE 3. Relative abundance of aquatic insects among functional feeding groups in sites at three altitudes (1500 m: A sites; $900 \mathrm{~m}$ : B sites; $500 \mathrm{~m}$ : C sites). A1, B1 and C1 are undammed sites and other sites are near check dams (above dams are even numbered:

$\mathrm{A} 2, \mathrm{~A} 4, \ldots$ and below dams are odd-numbers $>1$ : A $3, \mathrm{~B} 3, \ldots)$

The three most common insect taxa at each site are shown in Table 2. Shredders in both undammed and dam sites were mainly Lepidostomatidae (Trichoptera: Lepidostoma spp.), which were found mostly in leaf pack habitats during low flow periods (March - April and January - February) and in streamside vegetation during the high flow period (May - December). Lepidostoma spp. was especially common at B sites. Filter feeders at undammed and below dam sites were primarily Hydropsychidae (Trichoptera: Diplectrona spp.) at the $1500 \mathrm{~m}$ altitude, whereas Simuliidae (Diptera: Simulium spp.) dominated at the $900 \mathrm{~m}$ and $500 \mathrm{~m}$ altitudes. The most common collector-gatherers were Baetidae (Ephemeroptera), which Baetiella spp. was dominant at undammed and below dam sites of $900 \mathrm{~m}$ and $500 \mathrm{~m}$ altitudes. Baetis spp. (Baetidae) was common in the above dam site of those altitudes. At the $1500 \mathrm{~m}$ altitude, Baetidae was dominant in the undammed site, but Chironomidae (Clinotanypus spp. and Polypedilum spp.) was dominant in the corresponding dam sites. The dominant predators in several undammed and below dam sites (A1, B3, C1, C3 and C5) were Perlidae (Plecoptera: Etrocorema spp. and Phanoperla spp.), whereas Notonectidae (Hemiptera: Enithares spp.) was most abundant at above dam sites at the $1500 \mathrm{~m}$ altitude sites (A2 and A4). Dominant scrapers varied with altitude. Among the Heptageniidae (Ephemeroptera), Asionurus spp. was common at all $1500 \mathrm{~m}$ altitude sites, whereas Epeorus spp. was the dominant scraper at the undammed sites at $900 \mathrm{~m}$ and $500 \mathrm{~m}$ altitudes (B1 and C1). Marilia spp. (Odontoceridae: Trichoptera) was the main scrapers at dam sites at $500 \mathrm{~m}$ altitude (C2-C5).

The relationship between the proportions of shredders and leaf pack habitat was positively significant $(r=0.51$, $p<0.01)$. Although the correlation between the proportion of scrapers and canopy cover was not significant, below dam sites had higher canopy cover (and presumably less periphyton) than the corresponding undammed sites and tended to have a lower proportion of scrapers. 
TABLE 2. The most common insects at each sampling site

\begin{tabular}{|c|c|c|c|}
\hline $\mathrm{A} 1$ & $\begin{array}{l}\text { Diplectrona spp. } \\
\text { (16\%; Trichoptera) }\end{array}$ & $\begin{array}{l}\text { Baetis spp. } \\
\text { (13\%; Ephemeroptera) }\end{array}$ & $\begin{array}{l}\text { Lepidostoma spp. } \\
\text { (8\%; Trichoptera) }\end{array}$ \\
\hline $\mathrm{A} 2$ & $\begin{array}{l}\text { Clinotanypus spp. } \\
\text { (19\%:Diptera) }\end{array}$ & $\begin{array}{l}\text { Gyrinus spp. } \\
\text { (10\%:Coleoptera) }\end{array}$ & $\begin{array}{l}\text { Enithares spp. } \\
\text { (7\%:Hemiptera) }\end{array}$ \\
\hline A3 & $\begin{array}{l}\text { Simulium spp. } \\
\text { (15\%:Diptera) }\end{array}$ & $\begin{array}{l}\text { Polypedilum spp. } \\
\text { (11\%:Diptera) }\end{array}$ & $\begin{array}{l}\text { Baetis spp. } \\
\text { (8\%:Ephemeroptera) }\end{array}$ \\
\hline A4 & $\begin{array}{l}\text { Cloeon spp. } \\
\text { (25\%:Epemeroptera) }\end{array}$ & $\begin{array}{l}\text { Polypedilum spp. } \\
\text { (18\%:Diptera) }\end{array}$ & $\begin{array}{l}\text { Enithares spp. } \\
\text { (8\%:Hemiptera) }\end{array}$ \\
\hline B1 & $\begin{array}{l}\text { Lepidostoma spp. } \\
\text { (23\%:Trichoptera) }\end{array}$ & $\begin{array}{l}\text { Baetiella spp. } \\
\text { (15\%:Ephemeroptera) }\end{array}$ & $\begin{array}{l}\text { Baetis spp. } \\
\text { (11\%:Ephemeroptera) }\end{array}$ \\
\hline B2 & $\begin{array}{l}\text { Lepidostoma spp. } \\
\text { (44\%:Trichoptera) }\end{array}$ & $\begin{array}{l}\text { Baetis spp. } \\
\text { (14\%:Ephemeroptera) }\end{array}$ & $\begin{array}{l}\text { Asionurus spp. } \\
\text { (3\%:Ephemeroptera) }\end{array}$ \\
\hline B3 & $\begin{array}{l}\text { Lepidostoma spp. } \\
\text { (24\%:Trichoptera) }\end{array}$ & $\begin{array}{l}\text { Baetis spp. } \\
\text { (7\%:Ephemeroptera) }\end{array}$ & $\begin{array}{l}\text { Simulium spp. } \\
\text { (5\%:Diptera) }\end{array}$ \\
\hline $\mathrm{C} 1$ & $\begin{array}{l}\text { Simulium spp. } \\
\text { (73\%:Diptera) }\end{array}$ & $\begin{array}{l}\text { Baetiella spp. } \\
\text { (9\%:Ephemeroptera) }\end{array}$ & $\begin{array}{l}\text { Chimarra spp. } \\
\text { (6\%:Trichoptera) }\end{array}$ \\
\hline $\mathrm{C} 2$ & $\begin{array}{l}\text { Baetis spp. } \\
\text { (18\%:Ephemeroptera) }\end{array}$ & $\begin{array}{l}\text { Polypedilum spp. } \\
\text { (9\%:Diptera) }\end{array}$ & $\begin{array}{l}\text { Setodes spp. } \\
\text { (7\%:Trichoptera) }\end{array}$ \\
\hline C3 & $\begin{array}{l}\text { Simulium spp. } \\
\text { (28\%:Diptera) }\end{array}$ & $\begin{array}{l}\text { Baetiella spp. } \\
\text { (21\%:Ephemeroptera) }\end{array}$ & $\begin{array}{l}\text { Baetis spp. } \\
\text { (6\%:Ephemeroptera) }\end{array}$ \\
\hline $\mathrm{C} 4$ & $\begin{array}{l}\text { Setodes spp. } \\
\text { (24\%:Trichoptera) }\end{array}$ & $\begin{array}{l}\text { Baetis spp. } \\
\text { (15\%:Ephemeroptera) }\end{array}$ & $\begin{array}{l}\text { Limonia spp. } \\
\text { (6\%:Diptera) }\end{array}$ \\
\hline $\mathrm{C} 5$ & $\begin{array}{l}\text { Simulium spp. } \\
\text { (35\%:Diptera) }\end{array}$ & $\begin{array}{l}\text { Baetiella spp. } \\
\text { (9\%:Ephemeroptera) }\end{array}$ & $\begin{array}{l}\text { Baetis spp. } \\
\text { (4\%:Ephemeroptera) }\end{array}$ \\
\hline
\end{tabular}

\section{DISCUSSION}

Headwaters or low-order streams with heavy shade, which reduces periphyton production, rely on terrestrial organic input as energy and nutrient sources. Shredders process this terrestrial organic matter (Vannote et al. 1980) and are commonly abundant in temperate headwaters but are less abundant and diverse in tropical and regulated temperate streams (Boyero et al. 2011; Dobson et al. 2002; Dudgeon 2000; Fleituch 2003; Yule et al. 2009). The reduced dominance of shredders in the litter breakdown process in many tropical streams may result from a higher rate of microbial activity in the warmer water temperatures of these streams (Boyero et al. 2009; Dobson et al. 2002). In the study, the number of shredder taxa was low (8.8\% of total taxon richness) - which is similar to other studies in Thai (10\%) and Kenyan streams (0-10\%) (Boonsoong et al. 2009; Dobson et al. 2002). The relative abundance of shredders (13\% of all FFG) was also low, although an even lower percent composition was found in the study stream before check dam construction (3-4\%) (Nuntakwang 2001). Shredder abundance was highest at the middle, 900 $m$ altitude site, as discussed below, which raised the overall proportion of shredders. Shredders comprised $8.6 \%$ and $5.6 \%$ of FFG at the altitude $1500 \mathrm{~m}$ and $500 \mathrm{~m}$ sites, which is comparable to levels in other tropical streams, such as other streams in Thailand (0.2-4.7\%) and in Hong Kong (0.1-8.8\%) (Deemool \& Prommi 2015; Dudgeon 1989; Thanee \& Phalaraksh 2012).
The high proportion of shredders $(32 \%)$ at the 900 $\mathrm{m}$ sites is consistent with the similarly high leaf pack abundance at these sites. Habitat characteristics may play a role in shredder distribution (Cheshire et al. 2005; Yule et al. 2009). For example, variation in the leaf-falling period of different tree species in tropical streams can support a variety of specialist shredder species (Cheshire et al. 2005). In addition to the timing of leaf fall, plant tissue characteristics and organic chemical leachates of each tree species influence the colonization of aquatic hyphomycete fungi, which affect shredder feeding (Cummins 2016). However, although riparian plants are highly diverse, the richness of riparian and litter species may be inversely related to shredder abundance in tropical streams (Boyero et al.2011). Shredders in the study area were dominated by the caddisfly genus Lepidostoma. Lepidostoma spp. have a flexible feeding strategy (consuming many leaf types and having wide trophic niche), fast litter processing rate and rapid recolonization, making them strong competitors against other shredder taxa (Azevedo-Pereira et al. 2006; Dudgeon 2000; Whiles \& Wallace 1995), especially under conditions with high physical defense of leaves (e.g. leaf toughness) and limited consumable plant species. Cobbles from broken dam materials near rock-fill dam at middle altitude may support leaf accumulation and distribution of Lepidostoma spp. in adjacent areas.

Collectors are commonly abundant in streams and typically increase in abundance with stream size (Vannote et al. 1980). In this study, collectors had high relative 
abundance at all sites, except site B2 (above dam site at $900 \mathrm{~m}$ altitude), where a high proportion of leaf pack habitat supported many shredders. Filter-feeders, which rely on water flow to filter food from the water column, had low abundance at sites above dams due to slow flow in the water backed up by dams, whereas these conditions promoted collector-gatherers. The high relative abundance of gatherers in Huay Kaew stream is found in other regulated streams (Fleituch 2003; McDowell \& Naiman 1986). Accumulation of fine detritus in the backed-up water above dams promoted the high abundance of collectorgatherers (Rabení et al. 2005).

Scrapers had the overall lowest relative abundance among the FFGs in the study. Relative abundance of scrapers was not correlated with canopy cover, which might impact periphyton populations. Dudgeon (1989) also found no difference in scraper density between shaded and unshaded streams but found a strong negative relationship with detritus that may obstruct light penetration or interfere with grazing. In our study, fine detritus and sedimentation were greatest at sites above dams, but dips in the relative abundance of grazers above dams were not consistent among sites.

Predators normally have a similar proportion throughout the length of a stream channel, according to the river continuum concept or, alternatively, their abundance may depend on prey availability (Lugthart \& Wallace 1992; Vannote et al. 1980). Relative abundance of predators in the study stream was ranked as a second-most abundant group (following collectors); a result that is similar to that in a study on a Thai regulated river (Sirisinthuwanich et al. 2017). The percent composition of predators was higher in above dam sites relative to other sites in the same altitude. This higher proportion was associated with the pool habitat formed by the check dams and the associated pond-dwelling taxa that do not normally occur in flowing water stream sections (e.g. backswimmers: Enithares spp. and Paraplea spp.) and provide a new, local food source. The FFG method is a useful tool for stream quality assessment because it shows information about food resources and is integrated with habitat and stream ecosystem attributes (Cummins 2016; Merritt \& Cummins 2006). Shredders are important in the leaf breakdown process and produce fine particulate organic matter (FPOM), which is transported downstream (Wallace et al. 1982). An abundance of collectors indicates a high amount of fine detritus (mostly FPOM) in the stream. Scraper abundance can be related to algal primary production, which is in turn affected by available nutrients and light. Predator abundance affects prey populations. Percent composition of FFG affect nutrient cycling in stream systems and reflect the proportion of herbivores, carnivores, omnivores and detritivores in stream food webs. However, the limitations of FFG categorization should also be considered. Analyzing the feeding apparatus and gut contents classify some taxa into different groups. Feeding apparatus shows morphological-behavioral adaptation or feeding mechanism that represents size and location of food resources (Merritt \& Cummins 2006). The gut content method relies on the diet that is actually consumed (Cheshire et al. 2005), though consumption may vary temporally and spatially. For example, an insect species in different streams that have different available foods can have different gut contents (Cummins 2016). Moreover, some insect taxa change their feeding mode in response to different environmental conditions and growth stages (Boyero et al. 2009; Dudgeon 1989). Therefore, more research on feeding by aquatic insects is needed to improve FFG classification, especially in less studied areas.

\section{CONCLUSION}

The most dominant FFG group in Huay Kaew Stream was collector-gatherers, followed by filter-feeders, predators, shredders and scrapers. Check dams promoted suitable habitats for collector-gatherers and predators. A high abundance of collector-gatherers was associated with fine sediment accumulation above check dams, where slow flow restricted filter-feeders. Predators dominated in reservoirs above check dams, where pond-dwelling predators occurred. Shredder abundance varied among sites and was highest where leaf packs were most abundant. The least abundant FFG guild was scrapers, which were inconsistent with the dams. Free-flowing stream sections had different FFG compositions than flow-regulated sections. Specifically, leaf pack and detrital accumulations promoted shredders and collector-gatherers, respectively and pools provided a habitat for additional predator taxa. These effects of check dams were similar to FFG changes in other regulated streams. This study showed the effects of five check dams in protected area on disturbing FFG distribution that can lower stream functions. Numerous check dams along the stream and tributaries will also accumulate in larger changes in downstream. Therefore, the check dam concept that was originally created for degraded forest should be applied carefully in undegraded forest.

\section{ACKNOWLEDGEMENTS}

The Thailand Research Fund provided funding through the Royal Golden Jubilee Ph.D. Program (Grant number PHD/0143/2550). The Aquatic Insect Research Unit at Chiang Mai University provided facilities and field support. The research permit and cooperation of Doi Suthep-Pui National Park were appreciated.

\section{REFERENCES}

Allan, J.D. \& Castillo, M.M. 2007. Stream Ecology: Structure and Function of Running Waters. Netherlands: Springer Science \& Business Media.

Azevedo-Pereira, H.V.S., Graça, M.A.S. \& González, J.M. 2006. Life history of Lepidostoma hirtum in an Iberian stream and its role in organic matter processing. Hydrobiologia 559(1): 183-192.

Blakesley, D., Elliott, S., Kuarak, C., Navakitbumrung, P., Zangkum, S. \& Anusarnsunthorn, V. 2002. Propagation 
framework tree species to restore seasonally dry tropical forest: Implications of seasonal seed dispersal and dormancy. Forest Ecology and Management 164(1-3): 31-38.

Benfield, E.F. 2006. Decomposition of leaf material. In Methods in Stream Ecology, edited by Hauer, F.R. \& Lamberti, G.A. Burlington: Elsevier Inc. pp. 711-720.

Boonsoong, B., Sangpradub, N. \& Barbour, M.T. 2009. Development of rapid bioassessment approaches using benthic macroinvertebrates for Thai streams. Environmental Monitoring Assessment 155(1-4): 129-147.

Boyero, L., Pearson, R.G., Dudgeon, D., Graça, M.A.S., Gessner, M.O., Albariño, R.J., Ferreira, V., Yule, C.M., Boulton, A.J., Arunachalam, M. \& Callisto, M. 2011. Global distribution of a key trophic guild contrasts with common latitudinal diversity patterns. Ecology 92(9): 1839-1848.

Boyero, L., Ramírez, A., Dudgeon, D. \& Pearson, R.G. 2009. Are tropical streams really different? Journal of the North American Benthological Society 28(2): 397-403.

Bunn, S.E. \& Arthington, A.H. 2002. Basic principles and ecological consequences of altered flow regimes for aquatic biodiversity. Environmental Management 30(4): 492-507.

Cheshire, K., Boyero, L. \& Pearson, R.G. 2005. Food webs in tropical Australian streams: Shredders are not scarce. Freshwater Biology 50(5): 748-769.

Covich, A.P., Ewel, K.C., Hall Jr., R.O., Giller, P.S., Goedkoop, W. \& Merritt, D.M. 2004. Ecosystem services provided by freshwater benthos. In Sustaining Biodiversity and Ecosystem Services in Soils and Sediments, edited by Wall, D.H.London: Island Press. pp. 45-72.

Cummins, K.W. 2016. Combining taxonomy and function in the study of stream macroinvertebrates. Journal of Limnology 75(s1): 235-241.

Cummins, K.W. \& Klug, M.J. 1979. Feeding ecology of stream invertebrates. Annual Review of Ecology and Systematics 10(1): 147-172.

Cummins, K.W., Merritt, R.W. \& Andrade, P.C.N. 2005. The use of invertebrate functional groups to characterize ecosystem attributes in selected streams and rivers in south Brazil. Studies on Neotropical Fauna and Environment 40(1): 69-89.

Deemool, M. \& Prommi, T.O. 2015. Functional feeding groups of aquatic insects in the Mae Klong watershed for ecological assessment. Advances in Environmental Biology 9(26): 19-23.

Dobson, M., Magana, A., Mathooko, J.M. \& Ndegwa, F.K. 2002. Detritivores in Kenyan highland streams: More evidence for the paucity of shredders in the tropics? Freshwater Biology 47(5): 909-919.

Dudgeon, D. 2000. The ecology of tropical Asian rivers and streams in relation to biodiversity conservation. Annual Review of Ecology and Systematics 31(1): 239-263.

Dudgeon, D. 1999. Tropical Asian Streams: Zoobenthos, Ecology and Conservation. Hong Kong: Hong Kong University Press.

Dudgeon, D. 1989. The influence of riparian vegetation on the functional organization of four Hong Kong stream communities. Hydrobiologia 179(3): 183-194.

Elliott, S. 1994. The effects of urbanization on DoiSuthep-Pui National Park. Proceedings of the International Symposium on Urbanization and Forests. Thailand.

Fleituch,T. 2003. Structure and functional organization of benthic invertebrates in a regulated stream. International Review of Hydrobiology 88: 332-344.

Graça, M.A. 2001. The role of invertebrates on leaf litter decomposition in streams - A review. International Review of Hydrobiology 86: 383-393.
Lugthart, G.J. \& Wallace, J.B. 1992. Effects of disturbance on benthic functional structure and production in mountain streams. Journal of the North American Benthological Society 11: 138-164.

McDowell, D.M. \& Naiman, R.J. 1986. Structure and function of a benthic invertebrate stream community as influenced by beaver (Castor canadensis). Oecologia 68(4): 481-489.

Merritt, R.W. \& Cummins, K.W. 2006. Trophic relationships of macroinvertebrates. In Methods in Stream Ecology, edited by Hauer, F.R. \& Lamberti, G.A. Burlington: Elsevier. pp. 585-601.

Morse, J.C., Yang, L. \& Tian, L. 1994. Aquatic Insects of China Useful for Monitoring Water Qquality. Nanjing: Hohai University Press.

Nuntakwang, A. 2001. Aquatic insect functional feeding groups as indicators of stream ecosystem attributes and water qualities in Doi Suthep-Pui and Doi Inthanon National Park. Master's Thesis, Chiang Mai University, Thailand (Unpublished).

Prather, C.M., Pelini, S.L., Laws, A., Rivest, E., Woltz, M., Bloch, C.P., Toro, I.D., Ho, C., Kominoski, J., Scott Newbold, T.A., Parsons, S. \& Joern, A. 2013. Invertebrates, ecosystem services and climate change. Biological Reviews 88: 327-348.

Putiyanan, S. \& Maxwell, J.F. 2006. Survey and herbarium specimens of medicinal vascular flora of Doi Suthep-Pui. Chiang Mai University Journal of Natural Science 5(2): 169-178.

R Core Team. 2013. R: A Language and Environment for Statistical Computing. Austria. ISBN 3-900051-07-0, URL http://www.r-project.org.

Rabení, C.F., Doisy, K.E. \& Zweig, L.D. 2005. Stream invertebrate community functional responses to deposited sediment. Aquatic Sciences 67: 395-402.

Ramírez,A. \& Gutiérrez-Fonseca, P.E. 2014. Functional feeding groups of aquatic insect families in Latin America: A critical analysis and review of existing literature. Revista de Biologia Tropical 62(2): 155-167.

Sirisinthuwanich, K., Sangpradub, N. \& Hanjavanit, C. 2017. Impact of anthropogenic disturbance on benthic macroinvertebrate assemblages in the Phong River, Northeastern Thailand. AACL Bioflux 10: 421-434.

Suriyawong, P., Thapanya, D., Bergey,E.A.\& Chantaramongkol, P. 2015a. Macroinvertebrate community response to habitat alteration in a regulated mountain stream in DoiSuthep-Pui National Park, Thailand. Entomological Research Bulletin 31(1): 32-40.

Suriyawong, P., Thapanya, D., Bergey, E.A. \& Chantaramongkol, P. 2015b. Seasonal variation of aquatic insect communities and environmental characteristics in a regulated mountain

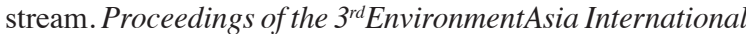
Conference. Bangkok, Thailand.

Thanee, I. \& Phalaraksh, C. 2012. Diversity of aquatic insects and their functional feeding group from anthropogenically disturbed streams in Mae Sot District, Tak Province, Thailand. Chiang Mai Journal of Science 39(3): 399-409.

Vannote, R.L., Minshall, G.W., Cummins, K.W., Sedell, J.R. \& Cushing, C.E. 1980. The river continuum concept. Canadian Journal of Fisheries and Aquatic Sciences 37(1): 130-137.

Wallace, J.B. 1990. Recovery of lotic macroinvertebrate communities from disturbance. Environmental Management 14(5): 605-620.

Wallace, J.B., Webster, J.R. \& Cuffney, T.F. 1982. Stream detritus dynamics: Regulation by invertebrate consumers. Oecologia 53: $197-200$. 
Whiles, M.R. \& Wallace, J.B. 1995. Macroinvertebrate production in a headwater stream during recovery from anthropogenic disturbance and hydrologic extremes. Canadian Journal of Fisheries and Aquatic Sciences 52: 2402-2422.

Yule, C.M., Leong, M.Y., Liew, K.C., Ratnarajah, L., Schmidt, K., Wong, H.M., Pearson, R.G. \& Boyero, L. 2009. Shredders in Malaysia: Abundance and richness are higher in cool upland tropical streams. Journal of the North American Benthological Society 28(2): 404-415.

Yule, C.M. \& Yong, H.S. 2004. Freshwater Invertebrates of the Malaysian Region. Malaysia: Academy of Sciences.

Phuchiwan Suriyawong*

Environmental Science Research Center, Faculty of Science Chiang Mai University 50200 Huay Kaew Road, Chiang Mai

Thailand
Decha Thapanya \& Porntip Chantaramongkol Department of Biology, Faculty of Science Chiang Mai University 50200 Huay Kaew Road, Chiang Mai

Thailand

Elizabeth A. Bergey

Oklahoma Biological Survey

University of Oklahoma

73019 Norman, OK

United States of America

*Corresponding author; email: phuchiwan_s@cmu.ac.th

Received: 5 September 2017

Accepted: 3 March 2018 